\title{
Coeliac disease: characterisation of monoclonal antibodies raised against a synthetic peptide corresponding to amino acid residues 206-217 of A-gliadin
}

\author{
H J Ellis, A P Doyle, R P Sturgess, P J Ciclitira
}

\begin{abstract}
A dodecapeptide of A-gliadin, which shares amino acid homologies with the E1b protein of adenovirus 12, was used to produce murine monoclonal antibodies. Five monoclonal antibodies were produced and were screened by. enzyme linked immunosorbant assay, immunodot assay, and immunoblotting. The antibodies were tested against whole wheat gliadin and its $\alpha, \beta, \gamma$, and $\omega$ subfractions, and the prolamins of rye, barley, oats, maize, millet, rice, and sorghum. Four of the five antibodies cross reacted with one or more of the coeliac non-toxic cereals - maize, millet, sorghum, and rice. The monoclonal antibody that did not cross react with these non-toxic cereals, did not recognise Frazer's fraction III, a peptic-tryptic digest of wheat gluten which is known to be toxic. The results suggest that the A-gliadin dodecapeptide shares a region of homology with cereals that do not exacerbate coeliac disease. This study does not support the hypothesis that prior infection with adenovirus 12 is a precipitating factor in coeliac disease.
\end{abstract}

(Gut 1992; 33: 1504-1507)

Coeliac disease is characterised by malabsorbtion secondary to damage of the normal villous architecture of the small bowel. The condition is thought to represent an aberrant HLA class II restricted immune response, mediated by antigen specific $T$ cells sensitive to certain cereal peptides. Coeliac disease is exacerbated by ingestion of wheat, rye, barley, and probably oats. The toxic fraction resides in the ethanol soluble storage protein, the prolamin fraction. ${ }^{1}$ Related cereals including maize, millet, sorghum, and rice, are not toxic to patients with coeliac disease. Efforts to identify the coeliac toxic amino acid sequence, which presumably acts as a $\mathrm{T}$ cell immunogen, have focussed on the wheat prolamin, gliadin, whose four subfractions $\alpha, \beta, \gamma$, and $\omega$, are thought to be toxic to patients with coeliac disease. ${ }^{23}$ The complete amino acid sequence of A-gliadin, one of the $\alpha$ gliadins, has been reported. ${ }^{+}$

Kagnoff has reported a region of sequence homology between part of A-gliadin and the $54 \mathrm{kD} \mathrm{Elb}$ protein of adenovirus 12.5 This homology is found in domain $\mathrm{V}$ of A-gliadin, ${ }^{+}$ between amino acid residues 206-217, which shares an identical pentapeptide (residues 211215) and three other amino acid identities with the Elb protein. It was postulated that prior infection with adenovirus 12 might predispose genetically susceptible individuals to the later development of coeliac disease. There have been conflicting reports of raised levels of neutralising, circulating antibodies to adenovirus 12 in coeliac patients. ${ }^{68}$ Persistent infection with adenovirus 12 has not been detected in the small bowel of patients with coeliac disease. ${ }^{910}$

We wished to demonstrate whether epitopes contained within the amino acid sequence 206217 of A-gliadin are specific to coeliac toxic cereals. Monoclonal antibodies have been raised against a synthetic peptide corresponding to this part of A-gliadin and their cross reactivities with prolamins that are toxic and non-toxic to patients with coeliac disease have been investigated.

\section{Methods}

PREPARATION OF ANTIGENS

A synthetic dodecapeptide of A-gliadin (residues 206-217) was kindly provided by Dr D Jewell, Radcliffe Infirmary, Oxford," and was conjugated to tuberculin purified protein derivative (PPD) to act as a carrier using $0 \cdot 05 \%$ glutaraldehyde. Whole gliadin and its $\alpha, \beta, \gamma$, and $\omega$ subfractions were prepared. ${ }^{12}$ The purity of the subfractions was checked by aluminium lactate starch gel electrophoresis. Visualisation of the gel, which had been overloaded with protein, showed only minimal cross contamination of the subfractions, with the exception of $\beta$ gliadin, which may have been contaminated with $5 \%$ of $\alpha$ and $\gamma$ gliadins. ${ }^{3}$ Prolamins from rye, barley, oats, millet, sorghum, maize, and rice were extracted from their respective flours at a concentration of $500 \mathrm{mg} / \mathrm{ml}$ in $50 \%$ ethanol. Frazer's fraction III was prepared as described. ${ }^{13}$ The protein contents of the cereal fractions were measured. ${ }^{1+}$

\section{IMMUNISATION}

Balb c mice that had been maintained on a gluten free diet for many generations in order to overcome oral tolerance to gliadin, ${ }^{15}$ were primed subcutaneously with $0 \cdot 1 \mathrm{ml}$ of $\mathrm{BCG}$ vaccine. Two, 4 , and 6 weeks later, the mice were injected with $30 \mu \mathrm{g}$ of the synthetic peptide conjugate in Freund's adjuvant. Murine antisera were screened against unfractionated gliadin by ELISA, as described below. Non-immunised mice on a gluten free diet served as controls. Thirty $\mu \mathrm{g}$ of peptide conjugate were then injected intravenously. 
TABLE I Titres of the five monoclonal antibodies produced against the synthetic A-gliadin peptide and the control antibody, $\mathcal{F} 13$, as determined by ELISA

\begin{tabular}{|c|c|c|c|c|c|c|c|c|c|c|c|c|c|c|}
\hline Clone & Gliadin & $\alpha$ & $\beta$ & $\gamma$ & (1) & $F F I I I$ & Rye & Barley & Oats & Maize & Rice & Millet & Sorghum & BSA \\
\hline KG9 & 2048 & 2048 & 2048 & 2048 & 64 & 4 & 16 & 512 & 2 & 128 & 1 & 2048 & 4 & - \\
\hline KG32 & 2048 & 512 & 64 & 16 & 1 & - & 1 & 8 & - & - & - & - & - & - \\
\hline KG42 & 256 & 64 & 128 & 128 & 128 & 128 & 64 & 256 & 64 & 64 & 2 & 128 & 16 & - \\
\hline KG53 & 512 & 64 & 64 & 256 & 32 & - & 512 & 512 & 64 & - & - & - & - & - \\
\hline KG62 & 256 & 16 & 32 & 64 & 16 & 2 & 4 & 2 & 32 & 4 & 4 & 256 & - & - \\
\hline J13 & - & - & - & - & - & - & - & - & - & - & - & - & - & - \\
\hline
\end{tabular}

FFIII = Frazer's fraction III; BSA = bovine serum albumin .

PRODUCTION OF MONOCLONAL ANTIBODIES Splenocytes were fused with murine myeloma cells (P3X63/Ag 8.653) ${ }^{16}$ using standard techniques. ${ }^{17}$ Hybridomas were screened by ELISA against unfractionated gliadin and those giving an optical density (OD) greater than 1.5 were single cell cloned. Clones were screened against unfractionated gliadin and expanded.
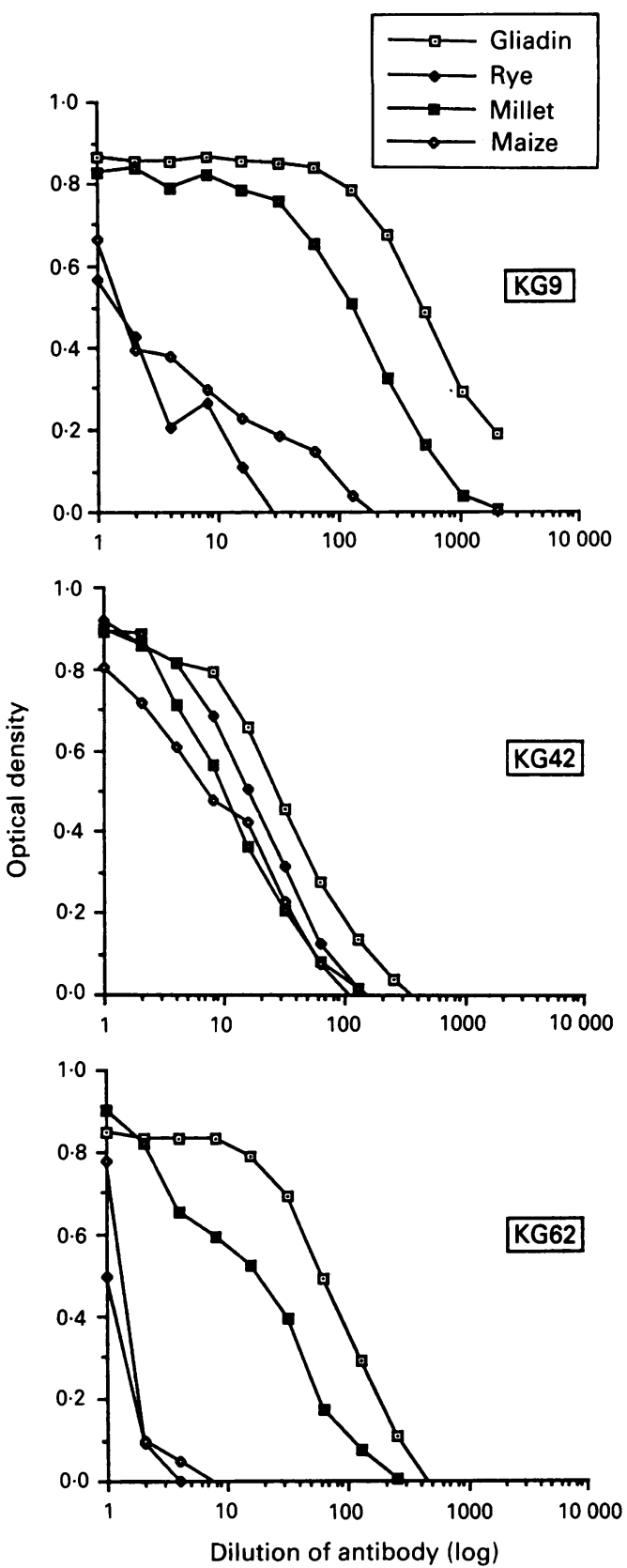

Figure 1: Titration curves determined by ELISA for monoclonal antibodies $K G 9, K G 42$, and KG62 against unfractionated gliadin, rye, maize and millet prolamins.
ELISA

ELISAs were performed as previously described. ${ }^{15}$ Plates were coated with unfractionated gliadin, its $\alpha, \beta, \gamma$, and $\omega$ subfractions, rye, barley, oats, maize, millet, or sorghum prolamins, at concentrations of $50 \mu \mathrm{g} / \mathrm{ml}$ in $70 \%$ ethanol. Frazers fraction III $(25 \mu \mathrm{g} / \mathrm{ml})$ was dissolved in carbonate-bicarbonate buffer, $\mathrm{pH}$ 9.6. Bovine serum albumin (BSA), $50 \mathrm{mg} / \mathrm{ml}$, served as a negative control. An irrelevant monoclonal antibody, J13, to human small intestinal brush border membranes served as a negative control. $^{18}$

\section{IMMUNODOT BINDING ASSAYS}

These were performed as previously described. Solutions of wheat gliadin and its subfractions, FFIII, rye, barley, and oat prolamins were used at a concentration of $500 \mu \mathrm{g} / \mathrm{ml}$ of Lowry positive protein. Casein and ovalbumin, $500 \mu \mathrm{g} /$ $\mathrm{ml}$, served as negative controls. Extracts of 500 $\mathrm{mg} / \mathrm{ml}$ of the flours of maize, rice, millet, and sorghum were applied directly to the nitrocellulose sheets irrespective of prolamin content. Monoclonal antibodies were used at a dilution of $1: 2$. A control antibody was used as above.

\section{SDS-PAGE AND IMMUNOBLOTTING}

This was performed as described. ${ }^{20}$ Seven $\mu \mathrm{g}$ of antigen were used per track. Blots were probed with monoclonal antibody supernatant at a dilution of $1: 2$.

\section{Results}

\section{IMMUNISATION}

Two mice immunised with the synthetic peptide conjugate showed serum titres to whole gliadin of $1: 6400$ and $1: 12800$ compared with a titre of 1:800 for a non-immunised mouse. The mouse with the highest titre was used.

PRODUCTION OF MONOCLONAL ANTIBODIES

The supernatants from 33 of the 108 wells gave positive ELISA readings against unfractionated gliadin; 12 with an OD greater than 1:5 were cloned. Five stable clones originating from five separate hybridomas were obtained.

ELISA

The titres of the five monoclonal antibodies produced against the synthetic A-gliadin peptide and the control antibody J13 are shown in Table I. Figure 1 shows titration curves for three of the 
TABLE II Monoclonal antibodies against test and control antigens determined by immunodot assay $(+++=$ strong spot; $++=$ moderate spot; $+=$ light spot; $+/-=$ trace; $-=$ no reaction)

\begin{tabular}{|c|c|c|c|c|c|c|c|c|c|c|c|c|c|c|c|}
\hline Clone & Gliadin & $\alpha$ & $\beta$ & $\gamma$ & (1) & FFIII & Rye & Barley & Oats & Maize & Rice & Millet & Sorghum & Casein & Ovalbumin \\
\hline $\begin{array}{l}\text { KG9 } \\
\text { KG32 } \\
\text { KG42 } \\
\text { KG53 } \\
\text { KG62 } \\
\text { J13 }\end{array}$ & $\begin{array}{l}+++ \\
++ \\
+++ \\
++ \\
+++ \\
-\end{array}$ & $\begin{array}{l}+++ \\
++ \\
+++ \\
++ \\
++ \\
-\end{array}$ & $\begin{array}{l}+++ \\
++ \\
+++ \\
++ \\
++ \\
+\end{array}$ & $\begin{array}{l}+++ \\
+ \\
+++ \\
++ \\
++ \\
-\end{array}$ & $\begin{array}{l}+1- \\
- \\
+++ \\
+1- \\
+ \\
-\end{array}$ & $\begin{array}{l}+1- \\
- \\
+1- \\
- \\
+1- \\
-\end{array}$ & $\begin{array}{l}+ \\
- \\
+++ \\
+ \\
++ \\
-\end{array}$ & $\begin{array}{l}+ \\
+1- \\
++ \\
+ \\
+ \\
-\end{array}$ & $\begin{array}{l}+ \\
+1- \\
++ \\
+ \\
+ \\
-\end{array}$ & $\begin{array}{l}++ \\
+1- \\
++ \\
- \\
+ \\
-\end{array}$ & $\begin{array}{l}++ \\
++ \\
++ \\
+1- \\
++ \\
-\end{array}$ & $\begin{array}{l}++ \\
+1- \\
++ \\
- \\
++ \\
-\end{array}$ & $\begin{array}{l}++ \\
- \\
++ \\
- \\
+ \\
-\end{array}$ & $\begin{array}{l}+1- \\
- \\
+1- \\
- \\
+1- \\
-\end{array}$ & $\begin{array}{l}- \\
+1- \\
+1- \\
- \\
+1- \\
-\end{array}$ \\
\hline
\end{tabular}

FFIII $=$ Frazer's fraction III.

antibodies. All antibodies cross reacted with gliadin and its $\alpha, \beta$, and $\gamma$ subfractions. Titres against $\omega$ gliadin were generally low. The monoclonal antibodies showed no, or very low, titres to Frazer's fraction III, with the exception of KG42. Three of the antibodies - KG9, KG42, and KG62 - showed cross reaction with the nontoxic cereals, particularly millet and maize.

\section{IMMUNODOT ASSAY}

The results for the test and control antibodies are presented in Table II. The dot assay obtained for KG42 is shown in Figure 2. All five antibodies cross reacted with gliadin and its $\alpha, \beta$, and $\gamma$ subfractions. Spots obtained with $\omega$ gliadin were generally very weak, with the exception of KG42 which gave a strong spot. KG9, KG42, and KG62 cross reacted with non-toxic maize, millet, sorghum, and rice confirming qualitatively the results of ELISA assays. KG53 reacted with gliadin and its subfractions, but did not react with the non-toxic cereals. KG32 showed cross reaction with rice, which was not apparent using ELISA. KG42 gave only a faint trace with Frazer's fraction III, the others did not react.

\section{SDS-PAGE AND WESTERN BLOTTING}

Binding was observed between antibody KG9 and rice and millet prolamins; maize prolamins displayed very weak bands and sorghum did not react in this system.

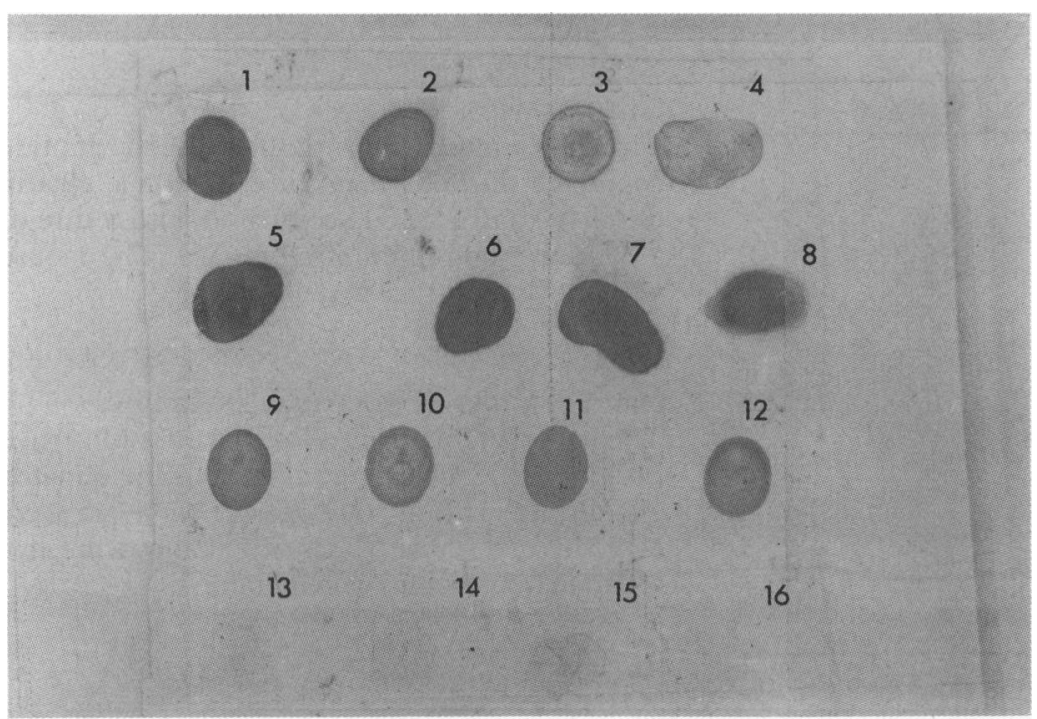

Figure 2: Immunodot assay: results for KG42. Antigens were as follows: (1) unfractionated gliadin, (2) rye, (3) barley, (4) oats, (5) a gliadin, (6) $\beta$ gliadin, (7) $\gamma$ gliadin, (8) 1 gliadin, (9) maize, (10) millet, (11) sorghum, (12) rice, (13) casein, (14) ovalbumin, (15) Frazer's fraction III, (16) blank.

\section{Discussion}

Coeliac disease probably represents an aberrant immune response by antigen specific $T$ cells of the small intestine to certain cereal peptides. It has been suggested that a peptide within A-gliadin, which has sequence homology with the Elb protein of adenovirus 12, may be an important epitope in the generation of such an aberrant immune response. We wished to establish whether epitopes within this peptide are specific to those cereal prolamins known to be toxic to patients with coeliac disease.

We have raised five monoclonal antibodies against a synthetic dodecapeptide of A-gliadin. Four of these antibodies showed cross reactivity with cereals that are not toxic in coeliac disease. Some differences were observed between the results obtained using ELISA and those with dot assay, which is considered to be more sensitive than ELISA. ${ }^{21}$ This may be explained, at least in part, by the greater antigen binding capacity of the solid phase, and might explain why some of the antibodies showed reactivity with antigens bound to nitrocellulose which they failed to recognise by ELISA. SDS-PAGE did not show the binding of antibody KG9 to sorghum prolamins which was observed using dot assay. This may be the result of a reduction in antigenicity caused by SDS.

Antibody KG53 did not react with the nontoxic cereals, suggesting that part of the dodecapeptide is unique to the toxic cereals. However, KG53 did not react with Frazer's fraction III, a physiological peptic-tryptic digest of gluten that is toxic in coeliac disease. This implies that the antibody is recognising an epitope that is cleaved by one of the digestive enzymes pepsin or trypsin. Thus, it seems unlikely that KG53 recognises a toxic amino acid sequence within A-gliadin. The amino acid sequence of the Agliadin peptide that has homology with the Elb protein of adenovirus 12 is: -Leu-Gly-Gln-GlySer-Phe-Arg-Pro-Ser-Gln-Gln-Asn-. The amine and carboxyl linkages of phenylalanine residues are susceptible to attack by pepsin and it is probable that the action of pepsin, either in vivo or during the preparation of Frazer's fraction III, cleaves the dodecapeptide.

Controversy exists as to the nature of the toxic moiety within gliadin. Analysis of A-gliadin peptides, including amino-acid residues 211217 , has shown that a potentially antigenic $\beta$ reverse turn is the predominant structural feature, involving residues -Arg-Pro-Ser-Gln-, which are also present in adenovirus 12."' Organ culture studies have shown that the tetrapeptide, -Pro-Ser-Gln-Gln-, is found in all coeliac active peptides. ${ }^{23}$ Residues 206-217 of A-gliadin 
incorporate this motif; however, in adenovirus 12 the final glutamine is replaced by a cysteine residue. In vitro studies have shown significant reactions to both synthetic A-gliadin and adenovirus 12 peptides from the regions of homology by leukocytes from coeliac patients." 24 However, a recent report using similar methodology, failed to show coeliac activity of a peptide containing the amino acid sequence $211-217$ of A-gliadin. ${ }^{25}$

Infusion of $100 \mathrm{mg}$ of the A-gliadin dodecapeptide caused some, but not significant, histological abnormalities in the jejunal mucosa of two treated coeliac patients. ${ }^{26}$ However, we have shown that $600 \mathrm{mg}$ of infused unfractionated gliadin produced significant changes in the crypt/villus ratio and epithelial cell height, with a doubling of the intraepithelial lymphocyte count within four hours of the challenge. ${ }^{3}$ Even assuming that gliadin contains more than one toxic moiety, a pure peptide would contain considerably more of the toxic moiety on a molar basis than whole gliadin. Allowing for intersubject variability, one might still expect to see marked changes in the histology of the small bowel after infusion of $100 \mathrm{mg}$ of pure peptide.

The data presented here suggest that there are sequence homologies between amino acid residues 206-217 of A-gliadin and non-toxic prolamins. Coeliac disease is thought to be a $\mathrm{T}$ cell mediated disorder, and since we have used monoclonal antibodies to dissect the antigenicity of these cereal peptides, we will have detected B cell epitopes within the peptides. The possibility therefore exists that there are specific $T$ cell epitopes within the adenovirus $12 \mathrm{E} 1 \mathrm{~b}$ protein A-gliadin sequence homology that are confined to coeliac toxic prolamins. Despite this qualification, we feel that the data presented do not support the hypothesis that prior infection with adenovirus 12 is a precipitating factor in coeliac disease.

The authors thank St Thomas's Research (Endowments) Committee; the Ministry of Agriculture, Fisheries and Food; Nutricia UK; and Semper AB, the American Institute of Cance Research, and the Jean Shanks Research Foundation for their support.

1 Kamer JHvd, Weijers HA, Dicke WK. Coeliac disease IV. An investigation of the injurious constituents of wheat in connection with their action on patients with coeliac disease. Acta Paediatr 1953; 42: 223-31.

2 Howdle PD, Ciclitra PJ, Simpson FG, Losowsky MS. Are all gliadins toxic in coeliac disease? An in vitro study of $\alpha, \beta, \gamma$ and $\omega$ gliadins. Scand $\mathcal{F}$ Gastroenterol 1984; 19: 41-7.

3 Ciclitira PJ, Evans DJ, Fagg NLK, Lennox ES, Dowling RH
Clinical testing of gliadin fractions in coeliac patients. Clin Sci 1984; 66: 357-64.

4 Kasarda DD, Okita TW, Bernadin JE, Backer PA, Nimmo C, Lew E, et al. Nucleic acid (cDNA) and amino acid sequences of $\alpha$ type gliadins from wheat (Triticum aestivum). Proc Natl Acad Sci 1984; 81: 4712-6.

5 Kagnoff MR, Raleigh KA, Hubert JJ, Bernadin JF, Kasarda $\mathrm{DD}$. Possible role of a human adenovirus in the pathogenesis of coeliac disease. $\mathcal{F}$ Exp Med 1984; 160: 1544-7.

6 Kagnoff MF, Paterson KJ, Kumar PJ, Kasarda DD, Carbone FR, Unsworth DJ, et al. Evidence for the role of a human intestinal adenovirus in the pathogenesis of coeliac disease. Gut 1987; 28: 995-1001.

7 Howdle PD, Blair Zadel ME, Smart CJ, Trejdosiewicz LK, Blair GE, Losowsky MS. Lack of a serologic response to an E1B protein of adenovirus 12 in coeliac disease. Scand $\mathcal{F}$ Gastroenterol 1989; 24: 282-6.

8 Dieleman LA, Pena AS, van Doornick JH, Mearin ML, van Duijn W, Lamers CBHW. No humoral response to the E1B-54kD protein of adenovirus 12 in patients with coeliac disease. Eur f Gastroenterol Hepatol 1991; 3: 255-7.

9 Carter MJ, Willcocks MM, Mitchison HC, Record CO, Madeley CR. Is a persistant adenovirus infection involved in coeliac disease. Gut 1989; 30: 1563-7.

10 Mahon J, Blair GE, Wood GM, Scott BB, Losowsky MS Howdle PD. Is persistant adenovirus 12 infection involved in coeliac disease? A search for viral DNA using the polymerase chain reaction. Gut 1991; 32: 1114-6.

11 Karagiannis JA, Priddle JD, Jewell DP. Cell-mediated immunity to a synthetic gliadin peptide resembling a sequence from adenovirus 12 . Lancet 1987 ; i: 884-6.

12 Patey AL, Evans DJ. Large scale preparation of gliadin proteins. F Sci Food Agric 1973; 24: 1229-33.

13 Frazer AC, Fletcher RF, Ross CAC, Shaw B, Sammons HG Scheider R. Gluten induced enteropathy: the effect of partially digested gluten. Lancet 1959; ii: $252-5$.

14 Lowry OH, Rosebrough NJ, Farr AL, Randall RJ. Protein measurement with the folin phenol reagent. $\mathrm{F}$ Biol Chem 1951; 193: 265-75.

15 Ellis HJ, Freedman AR, Ciclitira PJ. The production and characterisation of monoclonal antibodies to wheat gliadin peptides. F Immunol Methods 1989; 120: 17-22.

16 Kearney JF, Radbruch A, Liesegang B, Rajewsky K. A new mouse myeloma cell line that has lost immunoglobulin expression but permits the construction of antibody secreting hybrid cell lines. F Immunol 1979; 123: 1548-50

17 Galfre G, Milstein C. Preparation of monoclonal antibodies. Strategies and procedures. Methods Enzymol 1981; 73: 3-46.

18 Ellis HJ, Gal E, Nelufer JM, Freedman AR, Ciclitira PJ. Two monoclonal antibodies to human small intestinal brush border membrane components. Clin Sci 1987; 73 (suppl 17): 15.

19 Freedman AR, Galfre G, Gal E, Ellis HJ, Ciclitira PJ. Detection of wheat gliadin contamination of gluten-free foods by monoclonal antibody dot immunobinding assay. Clin Chim Acta 1987; 166: 323-8.

20 Freedman AR, Galfre G, Gal E, Ellis HJ, Ciclitira PJ. Western immunoblotting of cereal proteins. Int Arch Allergy Appl immunoblotting of cereal

21 Skerritt JH. A sensitive monoclonal-antibody-based test for gluten detection: quantitative immunoassay. $\mathcal{F} \mathrm{Sc}$ Food Agric 1985; 36: 987-94.

22 Tatham AS, Marsh MN, Wieser H, Shewry PR. Conformational studies of peptides corresponding to the coeliacactivating regions of wheat $\alpha$-gliadin. Biochem $\mathcal{F} 1990 ; 270$ 313-8.

23 de Ritis G, Auricchio S, Jones HW, Lew EJ-L, Bernardin JE, Kasada DD. In vitro (organ culture) studies of the toxicity of specific A-gliadin peptides in celiac disease. Gastroenterology 1988; 94: 41-9.

24 Mantzaris GJ, Karagiannis JA, Priddle JD, Jewell DP. Cellular hypersensitivity to a synthetic dodecapeptide Cellular hypersensitivity to a synthetic dodecapeptide
derived from human adenovirus 12 which resembles a derived from human adenovirus 12 which resembles a
sequence of A-gliadin in patients with coeliac disease. Gut sequence of A-gliadi.

25 Devery JM, Bender V, Penttila I, Skerritt JH. Identification of reactive synthetic gliadin peptides specific for coeliac disease. Int Arch Allergy Appl Immunol 1991; 95: 356-62.

26 Mantzaris G, Jewell DP. In vivo toxicity of a synthetic dodecapeptide from A-gliadin in patients with coeliac disease. Scand f Gastroenterol 1991; 26: 392-8. 